\title{
Evaluation of Preoperative Anxiety Level of Urological Surgery Patients and The Effects of Surgical Informing
}

\author{
(1) Mehmet Kutlu Demirkol, ${ }^{1}$ (1) Fatih Tarhan, ${ }^{2}$ 을 Özgür Yazıcl, ${ }^{3}$ \\ Mustafa Bilal Hamarat,, ํㅏ Alper Kafkaslı ${ }^{5}$
}

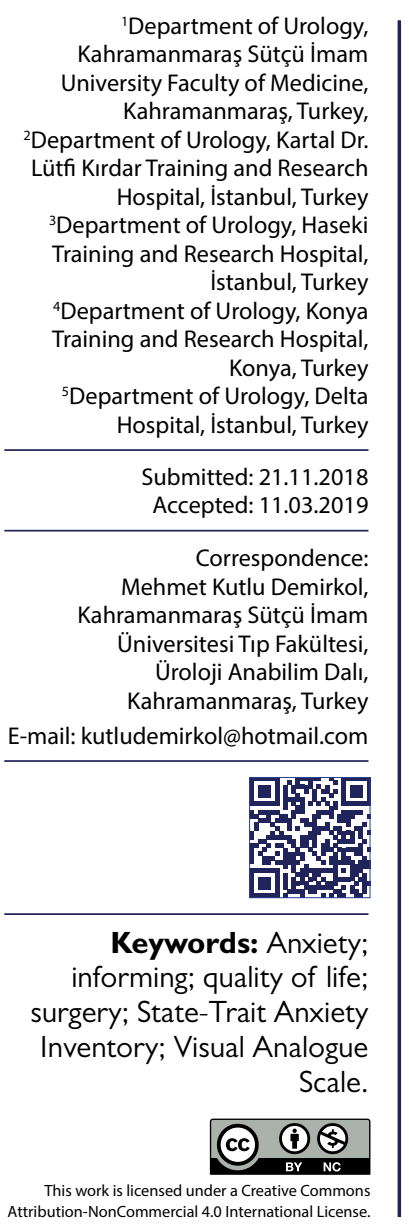

\begin{abstract}
Objective: To determine the causes of anxiety about surgery and to assess the impacts of informing about the surgical procedures on anxiety.

Methods: Between 18 and 65 years old, 497 patients who were scheduled for elective surgery in the Urology Clinic were included in this study. At the preoperative period, patients were asked to complete the following forms twice, before and after informing about surgery: State-Trait Anxiety Inventory (STAI), Visual Analogue Scale (VAS), European Quality of Life-5 Dimensions (EQ-5D) and the form containing causes of anxiety. Mean scores of STAI and VAS were classified as low, moderate, and high.
\end{abstract}

Results: The mean age of the patients was $56.54 \pm 0.58$ and the mean STAI value was 39. $16 \pm 0.42$. Factors increasing the level of anxiety were female gender, unemployment and lack of surgical history $(p<0.05)$. No statistically significant difference was found among STAI and VAS scores of the age, educational level, disease (benign - malign) and operation groups. The most frequent causes of anxiety were post-operative pain (38.3\%), fear of organ loss $(21.3 \%)$ and quality of life impairment (18.9\%). However, the first reason for anxiety in the group with a high anxiety score was fear of death. After the patients had been informed, the STAI and VAS scores increased. The anxiety levels increased after informing especially the patients who were unemployed women, low educated and undergoing group $A$ (major) operation $(p<0.05)$. STAI was positively correlated with VAS but negatively correlated with EQ-5D $(p<0.01)$.

Conclusion: It is observed that the patients who will undergo urological surgery have a moderate anxiety level and the most common cause is postoperative pain. Informing patients in the preoperative period increases the anxiety level. Hence, their quality of life is adversely affected. To understand the effects of informing on anxiety more clearly, new studies, including an uninformed control group, should be conducted.

\section{INTRODUCTION}

Surgical interventions have the potentials to cause serious psychiatric and psychosocial issues. They may lead to concerns that the patient will not be able to control his own body and life and fear of loss of organs or tissues, as well as hope and anticipation to get free of his/her disease. The level of this concern may vary depending on the nature of the underlying disease, in which an organ will be lost and the meaning and importance of the situation for the patient.
The patients undergoing surgical interventions may develop anxiety generally about anesthesia, concerns about the risk of death, worries about being disable, fear of pain, concerns on losing control on his/her own body, fear about loss of sexual function and ability to work. Studies have reported that approximately 60 to $80 \%$ of the patients in the preoperative period have anxiety. ${ }^{[1]}$ Level of anxiety has been found to be higher in women than in men, in the patients coming to the operation with his/her family or friends than the patients coming alone, in the 
patients undergoing cardiac or vertebral surgery, in young patients than in the elderly patients, and in the patients with poor past experience with anesthesia. ${ }^{[2]}$

Some studies have indicated that the level of preoperative and postoperative anxiety is lower, and postoperative pain is less and recovery occurs faster in the patients informed in a detailed manner in the preoperative period. ${ }^{[3]}$ According to a study, $82 \%$ of the patients undergoing surgery wanted to have more information about the surgical procedure, possible length of hospital stay. ${ }^{[4]}$ In another study, it was observed that not to be informed about the diagnosis and the anesthesia do not affect situational anxiety, but a low level of information about the surgical procedure leads to a high level of situational anxiety. ${ }^{[5]}$ The test most widely used in medicine to measure anxiety is the StateTrait Anxiety Inventory (STAI). ${ }^{[6,7]}$ Visual Analogue Scale (VAS) is also used in measuring the level of anxiety. ${ }^{[8]}$

In this study, we aimed to determine the causes of anxiety about surgical treatment, the effects of anxiety on quality of life and to assess the impacts of informing about the surgical procedure on anxiety in patients undergoing elective urological surgery.

\section{MATERIALS AND METHODS}

Eight hundred patients scheduled for elective surgery in the Urology Clinic between December 2012 and May 2013 were evaluated for the present study. Patients included in this study graduated from at least a primary school and could speak and understand the language. The subjects with known psychiatric disorders and any medical condition precluding the evaluation were excluded from this study. A total of 497 patients between 18 and 65 years old were included in this study. Permission for this study was received from the ethics committee of Dr. Lütfi Kırdar Kartal Training and Research Hospital on 14.02.2012 (no. 5 ), and written informed consent was obtained from all of the subjects.

Demographical characteristics of the patients, including age, gender and educational level, were recorded as well as their diagnosis and the scheduled operation. To determine the most common three causes of the anxiety in patients, a 9-item questionnaire developed by us, STAI measuring the situational anxiety, ${ }^{[6,7]}$ VAS which is another scale used to measure anxiety, ${ }^{[8]}$ and European Quality of Life-5 Dimensions (EQ-5D) -the index of overall quality of life-[9] were used. In this study, only the situational anxiety scale of the STAI was used to determine how a subject feels himself/herself at a certain time.

Five days before their operation, the subjects were asked to complete a sociodemographic data form, a form containing the causes of surgical anxiety, STAI, VAS and EQ-5D forms. Subsequently, the subjects were informed in a standard manner about their diagnosis and the scheduled operation. The patients were asked again to complete STAI, VAS and EQ-5D forms one day before preoperatively.
During the evaluation of the patients, the patients were divided into three groups based on their age as follows: 18-33 years, 34-49 years and 50-65 years. Mean scores of anxiety were classified as low, moderate, and high. For STAI, the low mean score was $<33$ points; the moderate mean score was 33-49 points and the high mean score was $>49$ points. ${ }^{[10]}$ Corresponding values for VAS was $<4$ points, 4-6 points, and $>6$ points. The calculated index score of the EQ-5D scale ranges from -0.59 to I. While a value of 0 indicates death and I full health, a negative value shows a state of unconsciousness and a bed-dependent condition. The operations were divided into groups determined by the Ministry of Health. Operations in the Group A were the specialty, those in the Group B were major, in the Group C were moderate, in the Group D were simple-moderate, and those in the Group E were simple operations. The co-morbidities of the patients were determined and graded by Charlson's Co-morbidity Index $(\mathrm{CCl}) .^{\left[{ }^{I I}\right]}$ According to this score, 0 points were mild, I-2 points were medium, 3-4 points were heavy and 5 or more points were classified as very severe.

All data were expressed as mean \pm standard deviation. Statistical analyses were performed using paired $t$, student $t$, ANOVA, Pearson's correlation, and Chi-square tests by the GraphPad Prism 5.0 software (GraphPad Software, San Diego, CA). P-value $<0.05$ was considered as statistically significant.

\section{RESULTS}

Of 497 patients, 368 (74.I\%) were male and I 29 (25.9\%) were female. Mean age of the subjects was $56.54 \pm 0.58$ years. Most of the patients were male, above 50 years old and graduate of primary school (Table I).

The mean STAI value was $39.16 \pm 0.42$. Most of the subjects had benign diagnoses, underwent operations of group $B$ and had history of previous surgeries (Table 2). $\mathrm{CCl}$ values of patients ranged from $\mathrm{I}$ to 6 and the mean was $0.89 \pm 0.06$. $\mathrm{CCl}$ grade was mild in 304 (6I.1\%) patient,

Table I. Socio-demographic characteristics of the patients

\begin{tabular}{llcc}
\hline & & $\mathbf{n}$ & $\%$ \\
\hline Sex & Male & 368 & 74.1 \\
& Female & 129 & 25.9 \\
Age groups & $<33$ years & 98 & 19.7 \\
& $34-49$ years & 172 & 34.6 \\
& $>50$ years & 227 & 45.7 \\
Marital status & Single & 47 & 9.5 \\
& Married & 439 & 88.3 \\
Educational level & Widow & 11 & 2.2 \\
& Primary school & 378 & 76.1 \\
& High school & 82 & 16.5 \\
& College & 37 & 7.4 \\
Employment status & Currently employed & 201 & 40.4 \\
& Unemployed & 296 & 59.6 \\
\hline
\end{tabular}


Table 2. Distribution of the patients by diagnosis, type of operation, and history of surgical operation

\begin{tabular}{llcc}
\hline & & $\mathbf{n}$ & $\%$ \\
\hline Diagnosis & Benign & 341 & 68.6 \\
& Malignant & 156 & 31.4 \\
Type of operation & Group A & 163 & 32.8 \\
& Group B & 284 & 57.1 \\
& Group C & 43 & 8.7 \\
& Group D & 5 & 1 \\
Previous operations & Group E & 2 & 0.4 \\
& No & 161 & 32.4 \\
& Yes & 336 & 67.6 \\
\hline
\end{tabular}

moderate in $144(28.9 \%)$, severe in $36(7.2 \%)$ and very severe in $13(2.6 \%)$.

\section{Results related to the causes of anxiety}

It was seen that the first reason for anxiety before the operation in the patients was anticipation of postoperative pain $(38.3 \%)$, the second reason was fear about the risk of body damage and loss of organ (21.3\%) and the third reason was fear about loss of job or daily performance or fear about impaired quality of life (18.9\%) (Table 3). It was observed that the first three reasons in the subjects with a low and moderate level of anxiety were the same as those in all patients (pain, loss of organ and loss of job). However, the first reason for anxiety in the group with a high anxiety score was fear of death, followed by pain and loss of an organ.

Anxiety scores were found to be higher in women, in the unemployed subjects and in women without a history of operation. No statistically significant difference was found among STAI and VAS anxiety scores of the age groups ( $p=0.077$ and $p=0.278$, respectively). There was no statistically significant difference between STAI and VAS scores of the subjects based on their educational level $(p=0.38 \mathrm{I}$ and $p=0.968$, respectively). In the present study, no statistically significant difference was found between STAI and VAS scores of the operation groups (Groups A-C) $(p=0.998$ and $p=0.219$, respectively). There was no significant difference between STAI and VAS scores of the subjects with benign and malignant conditions $(p=0.577$ and $p=0.605$, respectively).

\section{Results related to the anxiety scores}

An increase was observed in the anxiety scores after the patients had been informed $(p<0.05)$ (Table 4).

Informing about surgery increased the level of anxiety in the case of the female gender, lower educational level, unemployment, and operation of type A (Table 5). However, no statistically significant increase was observed after patients had been informed in the preoperative anxiety scores of the groups of the male gender, high educational level, active working people, undergoing major and moderate operations and all groups of age, marital status, diagnosis and operation history $(p>0.05)$.

Quality of life

EQ-5D index scores of patients ranged from -.02 to 1.00 . EQ-5D (Anxiety) is the depression/anxiety parameter of the five parameters of the EQ-5D scale. After informing patients, while the mean EQ-5D index scores decreased, the mean EQ-5D (Anxiety) scores increased, but both changes were not statistically significant, $p=0.5 \mathrm{I}$ and $p=0.34$, respec-

Table 4. STAI and VAS scores before and following giving information

\begin{tabular}{lcc}
\hline & STAI & VAS \\
\hline Before information & $39.16 \pm 0.42$ & $3.10 \pm 2.30$ \\
Following information & $39.77 \pm 0.45$ & $3.27 \pm 2.42$ \\
$\mathrm{P}^{*}$ & 0.035 & 0.018 \\
\hline
\end{tabular}

*Paired t-test. STAI: State-Trait Anxiety Inventory; VAS: Visual Analogue Scale.

Table 3. Reasons for anxiety before the operation

\begin{tabular}{|c|c|c|c|c|c|c|}
\hline \multirow[t]{2}{*}{ Reasons for anxiety } & \multicolumn{2}{|c|}{ Reason I } & \multicolumn{2}{|c|}{ Reason 2} & \multicolumn{2}{|c|}{ Reason 3} \\
\hline & $\mathbf{n}$ & $\%$ & $\mathbf{n}$ & $\%$ & $\mathbf{n}$ & $\%$ \\
\hline a- Insufficient knowledge of the surgeon & 24 & 4.8 & 3 & 0.6 & 10 & 2 \\
\hline b- Loss of control during anesthesia & 23 & 4.6 & 16 & 3.2 & 7 & 1.5 \\
\hline c- Fear of death & 90 & 18.1 & 30 & 6.1 & 22 & 4.4 \\
\hline d- Postoperative pain & 190 & 38.3 & 86 & 17.4 & 36 & 7.2 \\
\hline e- Insufficient knowledge on the procedure & 12 & 2.4 & 25 & 5.1 & 8 & 1.6 \\
\hline f- Fear of damage to the body, loss of organ & 45 & 9.1 & 106 & 21.3 & 92 & 18.5 \\
\hline g- Loss of job, performance following operation & 28 & 5.6 & 67 & 13.6 & 94 & 18.9 \\
\hline h- Fear of becoming dependent following operation & 3 & 0.6 & 14 & 2.6 & 47 & 9.5 \\
\hline I- Success of surgery (cure, recurrence) & 33 & 6.7 & 21 & 4.2 & 51 & 10.3 \\
\hline No anxiety & 49 & 9.8 & 129 & 25.9 & 130 & 26. 1 \\
\hline Total & 497 & 100 & 497 & 100 & 497 & 100 \\
\hline
\end{tabular}


Table 5. Mean anxiety scores based on female gender, lower educational level, unemployment and operation of type A

\begin{tabular}{lcccc}
\hline & Female gender & Lower educational level & Unemployment & Operation of type A \\
\hline STAI before & $42.19 \pm 0.86$ & $38.95 \pm 0.67$ & $39.72 \pm 0.55$ & $39.13 \pm 0.80$ \\
STAI after & $44.64 \pm 0.93$ & $39.98 \pm 0.51$ & $40.74 \pm 0.59$ & $40.08 \pm 0.87$ \\
P & 0.001 & 0.005 & 0.019 & 0.003 \\
VAS before & $3.87 \pm 0.22$ & $3.09 \pm 0.12$ & $3.30 \pm 0.14$ & $3.35 \pm 0.19$ \\
VAS after & $4.38 \pm 0.24$ & $3.31 \pm 0.12$ & $3.52 \pm 0.15$ & $3.69 \pm 0.20$ \\
P & 0.002 & 0.009 & 0.017 & 0.018 \\
\hline
\end{tabular}

*Paired t-test. STAI: State-Trait Anxiety Inventory; VAS: Visual Analogue Scale; EQ-5D: European Quality of Life-5 Dimensions; CCI: Charlson's Co-morbidity Index.

tively. A positive relationship was found between STAI and VAS, EQ-5D (Anxiety) ( $p<0.0$ I for both). A strong negative relationship was found between STAI and EQ-5D $(p<0.01)$. Based on these results, an increased level of anxiety of the subjects negatively affects their quality of life.

\section{DISCUSSION}

Surgical interventions have the potentials to cause serious psychiatric and psychosocial issues. The patients undergoing surgical interventions may develop anxiety generally about anesthesia, concerns about the risk of death, worries about being disabled, fear of pain, concerns about losing control on his/her own body, fear about loss of sexual function and ability to work. Studies have reported that about 60 to $80 \%$ of the patients in the preoperative period have anxiety. ${ }^{[1]}$ Level of anxiety has been found to be higher in women than in men, in the patients coming to the operation with his/her family or friends than the patients coming alone, in the patients undergoing cardiac or vertebral surgery, in young patients than in the elderly patients, and in the patients with poor past experience with anesthesia. ${ }^{[2]}$

Anxiety at a certain level is considered as a normal response to hospitalization and operation in the patients undergoing surgical procedures. Harmful effects begin to appear with an increasing level of anxiety. Anxiety about the anesthesia and surgery negatively affects the surgical procedure as well as postoperative healing. ${ }^{[12]}$ Domar et al. ${ }^{[13]}$ reported the preoperative score of anxiety as 45 based on the STAI scale, whereas Gönüllü et al. ${ }^{[2]}$ reported the level of anxiety measured before giving information as 40,76 . The mean STAI score was $39.16 \pm 0.42$ in the present study.

In this study, the findings suggest that among the demographic characteristics, the gender had an influence on the level of anxiety and that women had much more anxiety than men. Many studies have reported that level of anxiety is higher in women than in men. ${ }^{[13,14]}$ Badner et al. ${ }^{[1]}$ attributed this difference to that anxiety was higher in women due to leaving the family, while some researchers attributed this to that women could much express their feelings and anxiety easier compared to men. ${ }^{[13,15]}$

In this study, there was no significant difference between the age groups concerning anxiety level. Some researchers have reported that age did not affect the level of anxiety $^{[1,13,16]}$ while Ramsey ${ }^{[17]}$ found that level of anxiety was higher in the middle age group and attributed it to that responsibility of the subjects to their family in the mid-age group was more than other age groups.

The present study showed that employed subjects had a higher level of anxiety. We can explain this by that most unemployed subjects were female and that women had a higher level of anxiety.

It was found that the subjects without a history of operations had higher level of anxiety. Some studies have demonstrated the effects of history of operation on the level of anxiety. ${ }^{[18,19]}$ Badner et al. ${ }^{[1]}$ found that a lack of surgical experience was related to a higher level of anxiety.

In the present study, no significant relationship was found between educational level and anxiety. Some studies have reported that the level of anxiety increases with increasing level of education, whereas others have reported that educational level does not affect the level of anxiety. ${ }^{[13,15]}$

No significant relationship was found between operation groups (A-C) and level of anxiety in this study. One study showed that the level of anxiety was higher in the patients scheduled for major surgical procedures than the patients scheduled for minor surgery and concluded that type of operation had effects on the preoperative emotional condition. ${ }^{[20]}$ It is usually accepted that the level of anxiety is higher in patients undergoing tumor surgery and surgeries, which have the risk of organ loss. ${ }^{[21]}$ However, no significant difference was found in anxiety scores between the groups with benign and malignant diseases in this present study. Norris and Baird reported that the level of anxiety was higher in patients of plastic surgery and gynecology. ${ }^{[18]}$ Some studies have reported that type of operation does not affect the level of anxiety. ${ }^{[1,13]}$

It was seen in this study that the first three reasons for preoperative anxiety were postoperative pain (38.3\%), fear of damage to the body, organ loss (21.3\%) and postoperative loss of job, performance and impaired quality of life (18.9\%). Furthermore, reasons for anxiety were found to be different between the subjects with a high and low level of anxiety. The most common reason for anxiety was postoperative pain in the group with low anxiety scores, while the most common reason was fear of death in the 
group with a high anxiety score. Chew et al. ${ }^{[22]}$ reported the most common reasons for anxiety as pain (39.4\%) and inability to awake after the operation (18.9\%), while Hume et al. ${ }^{[23]}$ reported the most common reasons for anxiety as awakening during operation ( $51.8 \%$ ), the inability to awake after the operation (43.4\%), and pain (38\%). In a study from our country, Ceyhan et al. ${ }^{[24]}$ reported these reasons as fear of death (30.6\%), pain during operation (22.6\%), whereas Sekerci et al. ${ }^{[25]}$ reported them as the inability to awake after the operation (5I.9\%) and any unexpected situation (22.1\%).

It has been suggested that informing the patients preoperatively reduces anxiety significantly. ${ }^{[2]}$ The effects of informing the patients in a very detailed manner on the anxiety are controversial. ${ }^{[19]}$ In the present study, it was seen that informing the patients preoperatively increased anxiety level. However, the level of anxiety measured after information can be determined higher than the actual level since the second measurement was performed one day before the operation. Additionally, it is considered that a long interval between both points of measurement may affect the impact of giving information. To eliminate this, making a comparison by forming a control group would yield better results. Lack of a control group was a limitation for the present study. It has been shown in the literature that there is no significant difference between measurements of anxiety conducted at different time points. Arellano et al. ${ }^{[26]}$ measured the anxiety level of their patients one week, one day and immediately before the operation and reported that there was no significant difference between the three groups. Study of Lichtor et al. ${ }^{[27]}$ aiming to determine whether measurements of anxiety level performed at different two-time points reflected the real level of anxiety reported that correlation as high as $70 \%$ occurred between the anxiety levels measured in the afternoon of one day before the operation and immediately before the operation.

In this study, the effects of informing the patients were studied in the sub-groups, and the findings showed that informing the female patients increased the level of their anxiety. Kiyohara et al. ${ }^{[5]}$ reported that surgical information had no effect on situational anxiety based on gender and that subjects informed about the surgical procedure had a lower level of anxiety. Additionally, it was also found that the level of anxiety increased in the unemployed subjects, those with lower educational level and those undergoing operations of Group A (major-special).

Increased level of anxiety of the patients negatively affects their quality of life. In the present study, a positive correlation was found between STAI and VAS scores. Many studies have reported that there is a correlation between STAI and VAS scores. ${ }^{[8,26,28]}$

The limitation of our study is the absence of the uninformed control group. Therefore, the actual impacts of informing on the level of anxiety were not well evaluated.

\section{CONCLUSION}

It was seen that the patients undergoing urological operations had a moderate level of anxiety and the most common cause of anxiety was postoperative pain. The female subjects, unemployed and those without a history of operation had a higher level of anxiety. There was a significant positive correlation between the anxiety scales and the scale of quality of life. In contrast to the literature, informing the patients preoperatively was observed to increase the level of anxiety. The impacts of informing on the level of anxiety will be better evaluated by new studies containing an uninformed control group.

Ethics Committee Approval

Approved by the local ethics committee.

Informed Consent

Retrospective study.

Peer-review

Internally peer-reviewed.

Authorship Contributions

Concept: M.K.D., F.T.; Design: F.T.; Supervision: F.T.; Materials: M.K.D.; Data: A.K., M.B.H., Ö.Y.; Analysis: F.T.; Literature search: M.K.D.; Writing: M.K.D.; Critical revision: M.K.D., F.T.

Conflict of Interest

None declared.

\section{REFERENCES}

1. Badner NH, Nielson WR, Munk S, Kwiatkowska C, Gelb AW. Preoperative anxiety: detection and contributing factors. Can J Anaesth 1990;37:444-7. [CrossRef]

2. Gönüllü M, Turan ED, Erdem LK, Başeşme E. Anestezi uygulanacak hastalarda endişe düzeyinin araştırılması. Türk Anest ve Rean Cem 1986;14:110-3.

3. Weis OF, Sriwatanakul K, Weintraub M, Lasagna L. Reduction of anxiety and postoperative analgesic requirements by audiovisual instruction. Lancet 1983;1:43-4. [CrossRef]

4. Bunker TD. An information leaflet for surgical patients. Ann R Coll Surg Engl 1983;65:242-3.

5. Kiyohara LY, Kayano LK, Oliveira LM, Yamamoto MU, Inagaki MM, Ogawa NY, et al. Surgery information reduces anxiety in the pre-operative period. Rev Hosp Clin Fac Med Sao Paulo 2004;59:51-6.

6. Spielberger CD, Gorsuch RL, Lushene RE, Vagg PR, Jacobs GA. Manual for the State-Trait Anxiety Inventory. Palo Alto: Consulting Psychologists Press; 1983.

7. Öner N, Le Compte A. Durumluk-Sürekli Kayg1 Envanteri El Kitabı. İstanbul: Boğaziçi Üniversitesi yayınları; 1985.

8. Vogelsang J. The visual analog scale: an accurate and sensitive method for self-reporting preoperative anxiety. J Post Anesth Nursing 1988;3:235-9.

9. Rabin R, de Charro F. EQ-5D: a measure of health status from the EuroQol Group. Ann Med 2001;33:337-43. [CrossRef]

10. Gorenstein C, Andrade L. Validation of a Portuguese Version of the Beck Depression Inventory and the State-Trait Anxiety Inventory in Brazilian subjects. Braz J Med Biol Res 1996;29:453-7.

11. Charlson ME, Pompei P, Ales KL, MacKenzie CR. A new method of 
classifying prognostic comorbidity in longitudinal studies: development and validation. J Chronic Dis 1987;40:373-83. [CrossRef]

12. Boeke $\mathrm{S}$, Jelecic $\mathrm{M}$, Bonke B. Pre-operative anxiety variables as possible predictors of post-operative stay in hospital. $\mathrm{Br} \mathrm{J}$ Clin Psychol 1992;31:366-8. [CrossRef]

13. Domar AD, Everett LL, Keller MG. Preoperative anxiety: Is predictable entity? Anesth Analg 1989;69:763-70. [CrossRef]

14. Moerman N, van Dam FS, Oosting J. Recollections of general anaesthesia: a survey of anaesthesiological practice. Acta Anaesthesiol Scand 1992;36:767-71. [CrossRef]

15. Shevde K, Panagopoulos G. A Survey of 800 patients' knowledge, attitudes, and concerns regarding anesthesia. Anesth Analg 1991;73:190-8. [CrossRef]

16. Moerman N, van Dam FS, Muller MJ, Oosting H. The Amsterdam preoperative anxiety and information scale (APAIS). Anesth Analg 1996;82:445-51. [CrossRef]

17. Ramsay MA. A survey of pre-operative fear. Anaesthesia 1972;27:396-402. [CrossRef]

18. Norris W, Baird WL. Preoperative anxiety: a study of the incidence and aetiology. Br J Anaesth 1967;39:503-9. [CrossRef]

19. Egbert LD, Battit G, Turndorf H, Beecher HK. The value of the preoperative visit by an anesthetist. A study of doctor-patient rapport. JAMA 1963;185:553-5. [CrossRef]

20. Spielberger CD, Sarason IG. Determination of anxiety in elective surgery patients. In: Chapman C, Cox G, editors. Stress and anxiety.
Washington, DC: Hemisphere; 1977.

21. Mackenzie JW. Daycase anaesthesia and anxiety. A study of anxiety profiles amongst patients attending a day bed unit. Anaesthesia 1989;44:437-40. [CrossRef]

22. Chew ST, Tan T, Tan SS, Ip-Yam PC. A survey of patients' knowledge of anaesthesia and perioperative care. Singapure Med J 1998;39:399402.

23. Hume MA, Kennedy B, Asbury AJ. Patient knowledge of anaesthesia and peri-operative care. Anaesthesia 1994;49:715-8. [CrossRef]

24. Ceyhan A, Basar H, İnan N, Yağmurdur H, Çetinbaş R, Parpucu M, et al. Türk toplumu anestezi hakkında neler biliyor, neler bilmiyor? Sendrom 2000;12:75-9.

25. Sekerci S, Akpek E, Göktug A, Çetinsoy BC, Karabıyık L, Erdemli Ö, et al. Hasta ve yakınları ile toplumun farklı kesimlerinin anestezi ve uygulamaları konusundaki bilgi ve davranısları. Anestezi Dergisi 2001;9:48-51.

26. Arellano R, Cruise C, Chung F. Timing of the anesthetist's preoperative outpatient interview. Anesth Analg 1989;68:645-8. [CrossRef]

27. Lichtor LJ, Johanson CE, Mhoon D, Faure EA, Hassan SZ, Roizen MF. Preoperative anxiety: does anxiety level the afternoon before surgery predict anxiety level just before surgery? Anesthesiology 1987;67:595-9. [CrossRef]

28. Millar K, Jelicic M, Bonke B, Asbury AJ. Assessment of preoperative anxiety: comparison of measures in patients awaiting surgery for breast cancer. Br J Anaesth 1995;74:180-3. [CrossRef]

\section{Ürolojik Cerrahi Hastalarında Ameliyat Öncesi Endişe Düzeyinin Değerlendirilmesi ve Cerrahi Bilgilendirmenin Etkisi}

Amaç: Cerrahi ile ilgili kaygı nedenlerini belirlemek ve cerrahi prosedür hakkında bilgilendirmenin endişe üzerine etkilerini değerlendirmek.

Gereç ve Yöntem: Üroloji kliniğinde elektif cerrahi planlanan 18-65 yaş arası 497 hasta çalışmaya alınmıştır. Ameliyat öncesi dönemde cerrahi hakkında bilgilendirme öncesi ve sonrası hastaların Durumluk-Süreklilik Kaygı Envanteri formu (STAI), Görsel Analog Skalası (VAS), Avrupa Yaşam Kalitesi 5-Boyut (EQ-5D) ve ameliyat hakkında endişe nedenlerini içeren formu doldurmaları istenmiştir. Ortalama STAI ve VAS skorları düşük, orta ve yüksek olarak sınıflandırılmıştır.

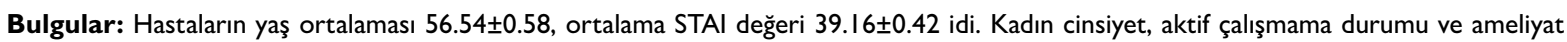
öyküsü olmaması kaygı düzeyini artıran faktörlerdi $(p<0.05)$. Yaş, eğitim düzeyi, hastalık (benin-malin) ve operasyon gruplarının STAI ve VAS anksiyete skorları arasında istatistiksel anlamlı bir fark bulunmadı. En sık görülen endişe nedenleri ameliyat sonrası ağrı (\%38.3), organ kaybı (\%2।.3) ve yaşam kalitesi bozulma korkusudur (\%|8.9). Ancak, kaygı puanının yüksek olduğu grupta ilk anksiyete nedeni ölüm korkusuydu. Hastalar bilgilendirildikten sonra STAI ve VAS anksiyete skorları arttı. Özellikle kadınlar, çalışmayanlar, düşük eğitim düzeyine sahip ve grup A (majör) operasyon geçiren hastaların bilgilendirildikten sonra endişe düzeyleri artmıştı $(p<0.05)$. STAI, VAS ile pozitif korelasyon gösterirken EQ-5D ile negatif korelasyon gösterdi $(\mathrm{p}<0.0 \mathrm{I})$.

Sonuç: Ürolojik cerrahi yapılacak hastaların orta derecede endişe düzeyine sahip olduğu ve en sık endişe nedeninin ameliyat sonrası ağrı olduğu görülmektedir. Çalışmamızda hastaların ameliyat öncesi dönemde bilgilendirmek kaygı düzeyini arttırmakta ve bu nedenle yaşam kaliteleri olumsuz yönde etkilenmektedir. Bununla birlikte, hasta bilgilendirilmesinin yapılmadığı kontrol grubu içeren yeni çalışmalar ile bilgilendirmenin endişe üzerindeki etkisi daha iyi anlaşılacaktır.

Anahtar Sözcükler: Bilgilendirme; cerrahi; Durumluluk Süreklilik Kaygı Envanteri; endişe; Görsel Analog Skalası; yaşam kalitesi. 